\title{
Rumen fermentation and retention time of the digesta in growing cattle of the breeds Black-White Dairy Cattle, Galloway, and Highland
}

Dedicated to Prof. Dr. habil. agr. H. Hagemeister on the occasion of his $65^{\text {th }}$ birthday

\begin{abstract}
Summary
The objectives of this study were to describe ruminal fermentation, mean retention time (MRT) of the particulate digesta in the whole gastrointestinal tract and the apparent digestibility of nutrients in growing cattle of the genotypes Black-White Dairy Cattle (B), Galloway $(\mathrm{G})$, and Highland $(\mathrm{H})$. Two experiments were carried out in bulls aged 11-12 months (mean weight $260 \mathrm{~kg}$ ) or $9-10$ months (mean weight $210 \mathrm{~kg}$ ) at the beginning and fed diets varying in the nutrient composition and nutrition level. B bulls had a higher rumenoreticular volume, a higher MRT when fed a low nutrition level, a higher ruminal $\mathrm{pH}$ and a lower acetate/propionate ratio in the rumen than $\mathrm{G}$ bulls $(\mathrm{P}<0.05)$. In comparison with $\mathrm{H}$ bulls, rumen $\mathrm{pH}$ and $\mathrm{MRT}$ were higher $(\mathrm{P}<0.05)$ and the acetate/propionate proportion, $\mathrm{NH}_{3}$ level, and the protozoa number in the rumen were smaller in $\mathrm{B}$ bulls. The differences between genotypes in apparent digestibility of organic matter (OM) and crude cellulose were small. In some cases digestibility was significantly $(\mathrm{P}<0.05)$ higher in $\mathrm{B}$ bulls as compared to $\mathrm{G}$ and $\mathrm{H}$ bulls. In $\mathrm{B}$ bulls, the digestibility of $\mathrm{OM}$ at $30^{\circ} \mathrm{C}$ environmental temperature was 2 units lower than at $3^{\circ} \mathrm{C}$ or $18^{\circ} \mathrm{C}(\mathrm{P}<0.05)$. The results show that $\mathrm{B}$ bulls implement a more efficient ruminal digestive process than do $\mathrm{G}$ or $\mathrm{H}$ bulls.
\end{abstract}

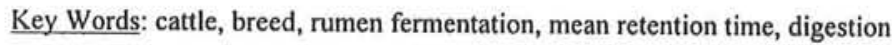

\section{Zusammenfassung}

Titel der Arbeit: Pansenfermentation und Retentionszeit der Digesta von Rindern der Rassen Schwarzbuntes Milchrind, Galloway und Highland

Das Ziel der Arbeit bestand darin, die Pansenfermentation, mittlere Retentionszeit der partikelgebundenen Digesta (MRT) im Gastrointestinaltrakt und die scheinbare Verdaulichkeit der Năhrstoffe bei wachsenden Bullen der Genotypen Schwarzbuntes Milchrind (B), Galloway $(G)$ und Highland $(\mathrm{H})$ vergleichend zu untersuchen. Dazu wurden 2 Experimente an Bullen, die zu Versuchsbeginn 11-12 Monate (mittlere LM $260 \mathrm{~kg}$ ) bzw. 9-10 Monate (mittlere LM $210 \mathrm{~kg}$ ) alt waren und mit Rationen unterschiedlichen Năhrstoffgehaltes bei differentem Ernăhrungsniveau gefuttert wurden, durchgefuhrt. Die B-Bullen besaßen im Vergleich zu den G-Bullen ein großeres Pansenvolumen, eine höhere MRT bei einem Emăhrungsniveau $\leq 1,4$, einen hőheren pH-Wert sowie ein engeres Acetat-Propionat-Verhăltnis im Pansen $(\mathrm{P}<0,05)$. Gegenuber den H-Bullen waren der pH-Wert im Pansen sowie die MRT erhőht und das Acetat-Propionat-Verhăltnis, der $\mathrm{NH}_{3}$-Spiegel und die Protozoenzahl im Pansen erniedrigt $(P<0,05)$. Die Differenzen in der scheinbaren Verdaulichkeit der organischen Substanz $(O M)$ und der Rohzellulose waren zwischen den Rassen gering; in Einzelfallen war die Verdaulichkeit bei den BBullen signifikant höher $(\mathrm{P}<0,05)$. Bei diesen Tieren sank die Verdaulichkeit der OM um 2 Einheiten, wenn die Umgebungstemperatur von 3 bzw. $18^{\circ} \mathrm{C}$ auf $30^{\circ} \mathrm{C}$ erhøht wurde $(\mathrm{P}<0,05)$. Die Ergebnisse zeigen, dass die ruminalen Verdauungsprozesse bei den B-Bullen effektiver ablaufen.

Schlüsselwörter: Rind, Genotyp, Pansenfermentation, Retentionszeit, Verdauung

\section{Introduction}

Breeds of cattle like Galloway $(\mathrm{G})$ or Highland $(\mathrm{H})$ used for extensive meat production on the one hand and breeds of cattle like Black-White Dairy Cattle (B) used for 
intensive milk or meat production on the other hand are adapted to different conditions over many generations. Thus, under poor conditions, robust breeds of cattle like Brahman crossbred are better able to maintain live weight than do cattle selected for high beef production (FRISCH and VERCOE, 1984; KENNEDY, 1982) which suggests that there were differences between breeds in feed efficiency. There is a lack of understanding of the mechanisms responsible for the observed difference in feed efficiency between breeds of cattle. Differences in the digestive process between breeds could be one of the reasons. However, in earlier studies only small or no differences were noted in the apparent digestibility of nutrients and energy between $\mathrm{G}$ and B animals (JENTSCH et al., 1994).

As part of a comparative study of physiology, the mean retention time of a particle marker in the gastro-intestinal tract, rumen fermentation and digestibility of diets differing in fibre content and nutrient level were studied in $\mathrm{G}, \mathrm{H}$, and $\mathrm{B}$ bulls. The results of digestibility have been published in detail (JENTSCH et al., 1995).

\section{Material and Methods}

\section{Experiment I}

Eight G and eight B bulls, initially 11-12 months of age and all of approximately 260 $\mathrm{kg}$ body weight (BW), were housed in individual pens in a metabolic house at 18-20 ${ }^{\circ} \mathrm{C}$ and a humidity of $70 \%$. They were given six diets in 10 experimental periods as shown in Table 1.

Table 1

Composition of the diets and nutrition level (Futtermittelanteile in den Rationen und Ernăhrungsniveau)

\begin{tabular}{|c|c|c|c|c|c|c|}
\hline \multirow{3}{*}{$\frac{\text { Diet }}{1}$} & \multicolumn{2}{|c|}{ Composition of the diet (\% Dry matter) } & \multicolumn{4}{|c|}{ Nutrition level' } \\
\hline & \multirow{2}{*}{$\begin{array}{l}\text { Experiment I } \\
55 \% \text { Rye grass hay } \\
45 \% \text { Barley }\end{array}$} & \multirow{2}{*}{$\begin{array}{l}\text { Experiment II } \\
40 \% \text { Rye grass hay } \\
40 \% \text { Hot air dried grass } \\
20 \% \text { Barley }\end{array}$} & \multicolumn{2}{|c|}{ Experiment I } & \multicolumn{2}{|c|}{ Experiment II } \\
\hline & & & 1.1 & 1.9 & 1.1 & 1.8 \\
\hline 2 & $\begin{array}{l}80 \% \text { Rye grass hay } \\
20 \% \text { Barley }\end{array}$ & $\begin{array}{l}50 \% \text { Rye grass hay } \\
50 \% \text { Hay from national park }\end{array}$ & 1.1 & 1.8 & 1.3 & - \\
\hline 3 & $\begin{array}{l}90 \% \text { Hot air dried grass } \\
10 \% \text { Dried sugar beet pulp }\end{array}$ & $\begin{array}{l}50 \% \text { Rye grass hay } \\
50 \% \text { Ray straw }\end{array}$ & 1.0 & 1.5 & 1.1 & - \\
\hline 4 & $\begin{array}{l}90 \% \text { Meadow grass hay } \\
10 \% \text { Dried sugar beet pulp }\end{array}$ & $\begin{array}{l}80 \% \text { Hot air dried grass } \\
20 \% \text { Barley }\end{array}$ & 1.0 & 1.4 & $1.5^{2}$ & - \\
\hline 5 & $\begin{array}{l}100 \% \text { Hay from national } \\
\text { park }\end{array}$ & & 1.0 & & & \\
\hline 6 & $\begin{array}{l}100 \% \text { Wheat straw } \\
(+42 \mathrm{~g} \text { Urea/(animal } \cdot \mathrm{d}))\end{array}$ & & 0.9 & & & \\
\hline
\end{tabular}

'Nutrition level I.0 $=450 \mathrm{~kJ} \mathrm{ME} /\left(\mathrm{kg} \mathrm{BW} \mathrm{W}^{0.73} \cdot \mathrm{d}\right) ;^{2}$ Diet was fed at three temperature levels $\left(3,18\right.$ and, $\left.30^{\circ} \mathrm{C}\right)$

Four diets were offered in two nutrition levels (low 1 times maintenance $(450 \mathrm{~kJ}$ $\left.\mathrm{ME} /\left(\mathrm{kg} \mathrm{BW}^{0.75} \cdot \mathrm{d}\right)\right)$, high $1.4-1.9$ times maintenance). The animals received equal 
portion of their diet daily at 07.00 and 15.30 hours. Additionally, $50 \mathrm{~g}$ of a mineralvitamin-mixture were given per animal and day. The chemical composition of the diets used is presented in Table 2. The diets were weighed out for each experimental period including a preliminary period of 18 days and a sampling period of 10 days. Representative samples of roughage and concentrate were oven dried $\left(65^{\circ} \mathrm{C}\right)$, air equilibrated, ground to pass a $1 \mathrm{~mm}$ sieve, and stored until to the analysis. Feed residues were collected daily, pooled over the sampling period, sampled and prepared for analyses as indicated for the diet samples.

Table 2

Energy content (MJ/kg DM) and chemical composition of the diets (g/kg DM) (Energiegehalt (MJ/kg TS) und chemische Zusammensetzung der Rationen ( $\mathrm{g} / \mathrm{kg}$ TS))

\begin{tabular}{|c|c|c|c|c|c|c|c|}
\hline Diets & $\begin{array}{l}\text { Gross } \\
\text { energy }\end{array}$ & $\begin{array}{l}\text { Organic } \\
\text { matter }\end{array}$ & $\begin{array}{l}\text { Crude } \\
\text { protein }\end{array}$ & $\begin{array}{l}\text { Crude } \\
\text { cellulose }\end{array}$ & Starch & $\begin{array}{l}\text { Cellulose/ } \\
\text { Starch }\end{array}$ & WSC' \\
\hline \multicolumn{8}{|c|}{ Experiment I } \\
\hline 1 & 18.06 & 945 & 103 & 181 & 292 & 0.6 & 103 \\
\hline 2 & 18.09 & 938 & 103 & 250 & 135 & 1.8 & 117 \\
\hline 3 & 18.30 & 899 & 174 & 290 & 16 & 18.1 & 66 \\
\hline 4 & 18.01 & 917 & 102 & 341 & 19 & 18.0 & 84 \\
\hline 5 & 18.45 & 942 & 64 & 391 & 20 & 19.6 & 72 \\
\hline 6 & 18.95 & 950 & $34^{2}$ & 443 & 2 & 221.5 & 6 \\
\hline \multicolumn{8}{|c|}{ Experiment II } \\
\hline 1 & 18.11 & 919 & 134 & 222 & 127 & 1.7 & 128 \\
\hline 2 & 18.24 & 933 & 92 & 325 & 4 & 81.2 & 128 \\
\hline 3 & 18.38 & 934 & 82 & 364 & 10 & 36.4 & 95 \\
\hline 4 & 17.86 & 893 & 153 & 216 & 127 & 1.7 & 78 \\
\hline
\end{tabular}

During the sampling period daily $10 \%$ of the days mixed faeces were collected with a level of accuracy of $\pm 10 \mathrm{~g}$ and stored at a temperature of $0-3{ }^{\circ} \mathrm{C}$. After homogenisation of the faeces at the end of the collection period, samples were taken to determine $\mathrm{N}$ and DM content. Two further samples each of $750 \mathrm{~g}$ were lyophilised and then ground through a $1 \mathrm{~mm}$ sieve. The daily urine excretion was collected in a canister and its $\mathrm{pH}$ was kept below 3 by addition of $3 \mathrm{M} \mathrm{H}_{2} \mathrm{SO}_{4}$. Urine sampling followed the same procedure as the faeces sampling. The samples were stored at $0-3{ }^{\circ} \mathrm{C}$ and after homogenisation used for $\mathrm{N}$ determination.

On the first day of the sampling period, the animals received a single dose of a pelleted $\mathrm{TiO}_{2}$-wheat flour mixture $\left(100 \mathrm{~g}\right.$ with $14 \mathrm{~g} \mathrm{TiO}_{2}$ per animal). Subsamples of faeces were collected $24,36,48,60,72,96$ and $120 \mathrm{~h}$ after dosage of $\mathrm{TiO}_{2}$. Rumen fluid was sampled by an oesophagus tube (STEGER et al., 1968) in the last day of each period 3 hours after morning feeding, transported into the laboratory and analysed for $\mathrm{pH}, \mathrm{NH}_{3}$, volatile fatty acids (VFA) and protozoa number.

In diet and faecal samples, the determination of dry matter (DM), ash, crude cellulose, and $\mathrm{N}$ was done following the Weender standard procedures (NAUMANN and BASSLER, 1988). Starch and water soluble carbohydrate were determined by the method of ZWIERZ et al. (1981). In faecal samples $\mathrm{TiO}_{2}$ was determined after Kjeldahl digestion by the method of BRAND and ALLAM (1987). The concentration 
of VFA in samples of rumen fluid was determined by gas chromatography with icapronic acid as internal standard (GEISSLER et al., 1976) using a SHIMADZU GC$14 \mathrm{~A}$ with an FFAP $25 \mathrm{~m} \times 0,25 \mathrm{~mm}$ I. D. column. $\mathrm{pH}$ was measured with a glass electrode and $\mathrm{NH}_{3}$ levels were determined by microdiffusion (VOIGT and STEGER, 1967).

The animals were slaughtered at an age of 18-19 months and a body weight of $300-$ $320 \mathrm{~kg}$. Subsequently, the volume of empty rumen was estimated in a water bath using pressures of 5 mbar above atmospheric pressure by the method described by NAGEL and PIATKOWSKI (1972).

\section{Experiment II}

The study was carried out in each 8 young $H$ bulls and 8 young B bulls aged 9-10 months and weighting initially $210 \mathrm{~kg}$ each. Housing of the animals was equal to Exp. I. The bulls were fed four diets in 7 experimental periods as shown in Table 1. The temperature in the metabolism chamber was maintained at $18{ }^{\circ} \mathrm{C}$, for diet 4 also at 3 ${ }^{\circ} \mathrm{C}$ and $30^{\circ} \mathrm{C}$. The animals were kept at these temperatures over a period of 10 days. The chemical composition of the diets is shown in Table 2.

The experimental procedure, feeding, sampling and analysis were carried out as in Exp. I. Additionally, Protozoa number in rumen fluid were determined by the method of FERBER and WINOGRADOWA-FEDEROWA (1929). The identification of rumen ciliate protozoa was done as described by DOGIEL (1927) and HUNGATE (1966). In each case 100 protozoa were counted and assigned to Holotrich protozoa (Isotricha, Dasytricha) and Ophryoscolecidae (Entodinium, Diplodinium, Ophryoscolex, Epidinium).

Calculations and statistical analysis

The mean retention time of the passage marker $\mathrm{TiO}_{2}$ (MRT) in the whole gastrointestinal tract was calculated according to BLAXTER (1956):

$$
M R T=\frac{\sum_{i=1}^{n}\left(t_{i} x m_{i}\right)}{\sum_{i=1}^{n} m_{i}}
$$

where $\mathrm{m}_{\mathrm{i}}$ is the amount of marker excreted at the $i$ th sample and $t_{i}$ is the time elapsed between dosing and the mid-point of the $i$ th collection interval.

The results were statistically analysed by ANOVA and multiple factorial GLM procedure of SPSS (Version 8.0; SPSS Inc.), and when appropriate, means were compared by the Scheffé multiple range test. Interactions were investigated and included in the model if they reached significance at the $5 \%$ level. When only breeds were compared, the Student's $t$ test was performed $(\mathrm{P}<0.05)$. 


\section{Results}

\section{Digestibility}

The digestibility of nutrients in Exp. I and II is shown in Table 3 and Table 4, respectively. For total diets in Exp. I, apparent digestibility of organic matter (OM) and crude cellulose in the whole gastrointestinal tract did not differ significantly between $\mathrm{G}$ and $\mathrm{B}$ cattle. Among bulls fed the low fibre high NL diet, B animals digested more $(\mathrm{P}<0.05) \mathrm{OM}$ than $\mathrm{G}$ animals did. The digestibility of $\mathrm{OM}$ and crude cellulose was also higher $(\mathrm{P}<0.05)$ in $\mathrm{B}$ bulls than in $\mathrm{G}$ bulls given the straw diet 6 .

Averaging all diets in Exp. II, B bulls digested more $(\mathrm{P}<0.05) \mathrm{OM}$ and crude cellulose than $\mathrm{H}$ bulls. The digestibility of $\mathrm{OM}$ in $\mathrm{B}$ bulls at $30^{\circ} \mathrm{C}$ was lower when compared with the 3 and $18^{\circ} \mathrm{C}$ treatment temperature $(\mathrm{P}<0.05)$.

Table 3

Experiment I: Intake of dry matter (DMI) and digestibility of nutrients (\%) (Means \pm SD) (Versuch I: Aufnahme an Trockensubstanz und Verdaulichkeit der Nahrstoffe; Mittelwerte $\pm s$ )

\begin{tabular}{|c|c|c|c|c|c|c|c|c|c|}
\hline \multirow[t]{3}{*}{ Diet } & \multirow[t]{3}{*}{ NL } & \multirow{2}{*}{\multicolumn{2}{|c|}{$\mathrm{n}$}} & \multirow{2}{*}{\multicolumn{2}{|c|}{ DMI $[g /(100 \mathrm{~kg} \mathrm{BW} \cdot \mathrm{d})]$}} & \multicolumn{4}{|c|}{ Digestibility } \\
\hline & & & & & & \multicolumn{2}{|c|}{ Organic matter } & \multicolumn{2}{|c|}{ Crude cellulose } \\
\hline & & G & $\mathrm{B}$ & G & B & $\mathrm{G}$ & B & G & $\mathrm{B}$ \\
\hline 1 & 1.1 & 8 & 8 & 1028 & 1013 & $80.8 \pm 1.4$ & $81.5 \pm 1.3$ & $78.5 \pm 2.4$ & $78.7 \pm 2.1$ \\
\hline 1 & 1.9 & 8 & 8 & 1705 & 1883 & $70.3 \pm 2.2^{4}$ & $73.5 \pm 2.1^{b}$ & $57.6 \pm 9.3$ & $63.2 \pm 5.2$ \\
\hline 2 & 1.1 & 8 & 8 & 1112 & 1115 & $78.3 \pm 1.1$ & $78.8 \pm 0.5$ & $83.1 \pm 1.4$ & $83.8 \pm 0.8$ \\
\hline 2 & 1.8 & 8 & 8 & 1856 & 1828 & $74.1 \pm 2.9$ & $73.6 \pm 2.0$ & $77.1 \pm 5.1$ & $77.5 \pm 2.8$ \\
\hline 3 & 1.0 & 4 & 4 & 1144 & 1135 & $71.3 \pm 0.5$ & $70.5 \pm 0.9$ & $80.4 \pm 0.8$ & $79.2 \pm 2.5$ \\
\hline 3 & 1.5 & 4 & 4 & 1781 & 1681 & $69.2 \pm 0.8$ & $68.1 \pm 1.4$ & $77.4 \pm 1.9$ & $76.1 \pm 2.8$ \\
\hline 4 & 1.0 & 3 & 4 & 1371 & 1295 & $62.9 \pm 0.8$ & $63.6 \pm 1.6$ & $67.9 \pm 1.0$ & $70.3 \pm 1.6$ \\
\hline 4 & 1.4 & 3 & 4 & 1885 & 1845 & $62.5 \pm 0.2$ & $61.5 \pm 0.9$ & $66.4 \pm 2.0$ & $66.7 \pm 3.1$ \\
\hline 5 & 1.0 & 8 & 8 & 1510 & 1481 & $57.9 \pm 0.9$ & $58.5 \pm 1.2$ & $68.0 \pm 2.0$ & $67.2 \pm 1.8$ \\
\hline 6 & 0.9 & 8 & 8 & 1159 & 1243 & $54.6 \pm 1.8^{\mathrm{a}}$ & $56.7 \pm 2.2^{b}$ & $68.3 \pm 2.2^{\mathrm{a}}$ & $70.9 \pm 2.6^{b}$ \\
\hline \multicolumn{2}{|c|}{ Total diets } & & & & & $68.2 \pm 8.6$ & $68.6 \pm 8.4$ & $72.5 \pm 8.0$ & $73.4 \pm 6.6$ \\
\hline
\end{tabular}

Table 4

Experiment II: Intake of dry matter (DMI) and digestibility of nutrients (\%) (Means \pm SD) (Versuch II: Aufnahme an Trockensubstanz und Verdaulichkeit der Năhrstoffe; Mittelwerte $\pm s$ )

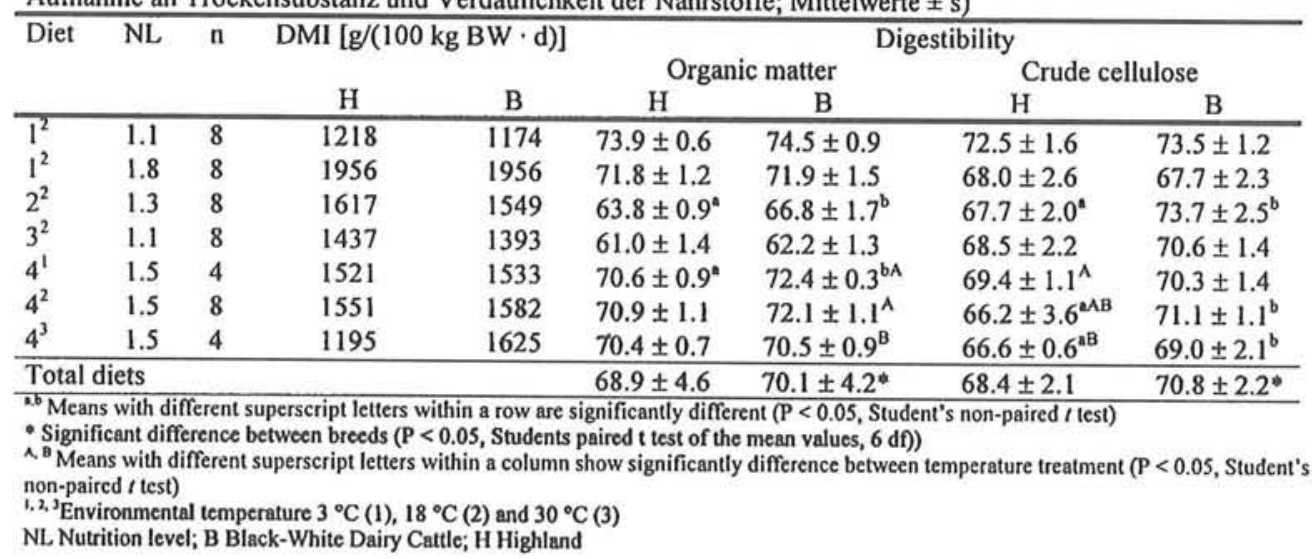


Table 5

Experiments I and II: Ruminal physiological parameters (Versuche I und II: Pansenphysiologische Kennwerte)

\begin{tabular}{|c|c|c|c|c|c|c|c|c|c|c|c|c|c|c|c|c|}
\hline Diet & $\mathrm{NL}$ & $\begin{array}{l}\text { Crude } \\
\text { fibre } \\
\mathrm{g} / \mathrm{kg} \mathrm{DM}\end{array}$ & & & & & & & Prop & & & & Acetate/ & opionate & & \\
\hline Expe & iment & & & & & & & & & & & & & & & \\
\hline & & & G & B & G & B & G & B & G & B & G & B & G & B & G & B \\
\hline 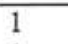 & 1.1 & 181 & 6.85 & 6.87 & 90.3 & 90.3 & $66.7^{2}$ & $64.3^{b}$ & 17.7 & 20.3 & 15.6 & 15.4 & 3.83 & 3.20 & 4.4 & 6.0 \\
\hline 1 & 1.9 & 181 & 6.55 & 6.61 & 99.6 & 95.2 & 61.8 & 61.4 & 21.3 & 21.4 & 16.9 & 17.2 & 2.98 & 2.93 & 1.7 & 2.1 \\
\hline 2 & 1.1 & 244 & 6.94 & 6.99 & 80.7 & 81.1 & $67.6^{2}$ & $64.9^{\mathrm{b}}$ & $18.7^{\mathrm{a}}$ & $22.9^{b}$ & 13.7 & 12.2 & 3.62 & 2.87 & 5.0 & 5.2 \\
\hline 2 & 1.8 & 244 & 6.55 & 6.72 & 92.0 & 96.0 & 65.3 & 64.2 & $20.0^{\mathrm{a}}$ & $23.0^{b}$ & 14.7 & 12.9 & 3.30 & 2.81 & 4.7 & 3.8 \\
\hline 3 & 1.0 & 282 & 6.96 & 7.02 & 71.8 & 71.4 & 76.2 & 75. & 15.3 & 15.6 & 8.5 & 8.9 & 5.00 & 4.84 & 11.7 & 10.9 \\
\hline 3 & 1.5 & 2 & 6.74 & 6.82 & 77.4 & 75.5 & 5.2 & 74.6 & 15.8 & 16.8 & 9.0 & 8.7 & 4.7 & 4.46 & 12.8 & 10.7 \\
\hline 4 & 1.1 & 348 & 6.86 & 6.86 & 77.0 & 72.2 & 71.7 & 72.8 & 20.9 & 18 & 7.4 & 8.2 & 3.4 & 3.85 & 5.8 & 7.3 \\
\hline 4 & 1.4 & 348 & 6.73 & 6.91 & 76.5 & 75.3 & 73.8 & 74. & 17.4 & 17. & 8.8 & 7.7 & 4.24 & 4.25 & 6.0 & 7.3 \\
\hline 5 & 1.0 & 392 & 6.83 & 6.96 & 68.8 & 69.9 & 74.4 & 74.4 & 16.8 & 17.5 & 8.9 & 8.0 & 4.44 & 4.27 & 2.7 & 4.0 \\
\hline 6 & 0.9 & 497 & $7.04^{a}$ & $7.24^{b}$ & 62.1 & 62.8 & 77.2 & 77.6 & 15.8 & 16.6 & 7.0 & 5.7 & 4.90 & 4.69 & 9.8 & 8.3 \\
\hline Total & diets & & 6.80 & $6.90^{*}$ & 80.9 & 80.5 & 70.1 & 69.8 & 18.1 & $19.3^{*}$ & 11.8 & 10.9 & 3.98 & $3.74^{*}$ & 5.8 & 5.9 \\
\hline $\begin{array}{l}\text { Pool } \\
\text { Inter }\end{array}$ & $\begin{array}{l}\text { d SE } \\
\text { action }\end{array}$ & & & & & & & & Bree & & & & & & & \\
\hline Expe & riment & & & & & & & & & & & & & & & \\
\hline & & & $\mathrm{H}$ & B & $\mathrm{H}$ & B & $\mathrm{H}$ & B & $\mathrm{H}$ & B & $\mathrm{H}$ & B & $\mathrm{H}$ & $B$ & $\mathrm{H}$ & $B$ \\
\hline 1 & 1.1 & 220 & 6.96 & 6.90 & 57.7 & 61.6 & 61.9 & 61.6 & $17.5^{2}$ & $21.1^{b}$ & $16.2^{2}$ & $12.7^{b}$ & $3.54^{2}$ & $2.92^{b}$ & $6.8^{\mathrm{a}}$ & $5.5^{b}$ \\
\hline 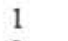 & 1.8 & 3 & 6.57 & 6.61 & 76.5 & 72.9 & 58.8 & 57.7 & $20.0^{\mathrm{a}}$ & $24.1^{\mathrm{b}}$ & $17.4^{2}$ & $14.3^{b}$ & $2.95^{\mathrm{a}}$ & $2.41^{\mathrm{b}}$ & $8.7^{\mathrm{a}}$ & $6.2^{b}$ \\
\hline 2 & 1.3 & 379 & 6.55 & 6.69 & 71.5 & 71.5 & 64.2 & 63.8 & 21.2 & 21.0 & 11.5 & 12.2 & 3.08 & 3.07 & $4.8^{\mathrm{z}}$ & $2.3^{\mathrm{b}}$ \\
\hline 3 & 1.1 & 23 & 6.66 & 6.80 & 67.5 & 60.6 & 65.3 & 65.5 & $20.4^{\mathrm{a}}$ & $22.7^{\mathrm{b}}$ & $10.8^{\mathrm{a}}$ & $8.6^{\mathrm{b}}$ & $3.21^{\circ}$ & $2.90^{\mathrm{b}}$ & $5.1^{\circ}$ & $3.6^{\mathrm{b}}$ \\
\hline $4^{1}$ & 1.5 & 238 & 7.13 & 7.27 & $54.9^{2 \mathrm{~A}}$ & $60.7^{b}$ & 70.9 & 70.7 & 14.4 & 13.9 & 10.2 & 10.1 & 4.96 & 5.1 & $7.1^{24}$ & $8.8^{\mathrm{b}}$ \\
\hline $4^{2}$ & 1.5 & 238 & 7.14 & 7.40 & $65.1^{\mathrm{B}}$ & 69.9 & 71.5 & 71.8 & $14.2^{2}$ & $13.4^{b}$ & $9.8^{a}$ & $10.7^{b}$ & $5.05^{3}$ & $5.39^{b}$ & $7.1^{24}$ & $7.6^{\mathrm{b}}$ \\
\hline $4^{3}$ & 1.5 & 238 & 7.17 & 7.37 & $52.3^{\text {aA }}$ & $64.9^{b}$ & 71.2 & 70.9 & 14.2 & 14.1 & 8.6 & 10.3 & 5.05 & 5.04 & $9.1^{B}$ & 8.3 \\
\hline & diets & & 6.88 & $7.00^{*}$ & 63.4 & 66.2 & 66.3 & 66.0 & 17.4 & $18.6^{*}$ & 12.1 & 11.4 & 3.98 & $3.84^{*}$ & 7.0 & $6.0^{*}$ \\
\hline Pool & d SE & & & & & & & & & & & & & Ce & & \\
\hline
\end{tabular}

Interaction $\quad$ Breed*Diet

(

- Significant difference between breeds ( $P<0.05$, three-factorial GLM in Exp. I, four-factorial GLM in Exp. II))

1.2, Environmental temperature $3(1), 18(2)$ and $30^{\circ} \mathrm{C}(3)$

G Galloway, $\mathrm{H}$ Highland, B Black-White Dairy Cattle 


\section{Rumen fermentation}

The differences between $\mathrm{G}$ and $\mathrm{B}$ bulls in mean $\mathrm{pH}$, mol-\% propionate and the acetate/propionate ratio were significant (Table 5). In comparison to G bulls, B bulls produced more propionate per mol VFA. There was no significant difference between $\mathrm{G}$ and $\mathrm{B}$ bulls in the concentration of ruminal $\mathrm{NH}_{3}$. In Exp. I, interactions were observed between breed and diet for $\mathrm{mol} \%$ propionate and $\mathrm{NH}_{3}$ level.

In Exp. II, the $\mathrm{pH}$ and the propionate ratio were higher and the acetate/propionate ratio and $\mathrm{NH}_{3}$ concentration were lower $(\mathrm{P}<0.05)$ in $\mathrm{B}$ bulls than in $\mathrm{H}$ bulls. The higher propionate level was particularly pronounced in diet 1 with a higher content of sugars.

The total number of protozoa significantly differed $(\mathrm{P}<0.05)$ between $\mathrm{H}$ and $\mathrm{B}$ animals. The protozoa population was larger in $\mathrm{H}$ bulls than in B bulls (Fig. 1). In $\mathrm{H}$ bulls, the proportion of holotricha was larger and that of ophryoscolecidae smaller than in $\mathrm{B}$ bulls $(\mathrm{P}<0.05)$.

\section{Mean retention time and rumen volume}

In Exp. II, the mean retention time (MRT) of the used particulate flow marker was higher $(\mathrm{P}<0.05)$ in $\mathrm{B}$ animals $(28.6 \pm 2.4 \mathrm{~h})$ than in $\mathrm{H}$ animals $(25.3 \pm 2.3 \mathrm{~h})$. In $\mathrm{H}$ bulls, but not in B bulls, MRT increased with growing temperature (Fig. 2).

As to MRT, in Exp. I there was no significant difference between the breeds (G $27.7 \pm$ $3.1 \mathrm{~h}, \mathrm{~B} 28.6 \pm 4.0 \mathrm{~h}$ ), however, the relationship between the nutrition level and the MRT appeared to be different (Fig. 4). The regression coefficient was lower $(\mathrm{P}<0.10)$ in $\mathrm{G}$ animals than in B bulls and so was the effect of NL on MRT. In comparison to G bulls, the rumen volume was larger in B animals (Fig. 3).

\section{Discussion}

The observed variation in the feed efficiency of cattle (ARCHER et al., 1999) can be based on differences in requirement for maintenance, body composition, proportion of visceral organs, level of physical activity, interactions to environmental conditions, and digestion efficiency. JENTSCH et al. $(1994,1995)$ found a $15 \%$ higher energy maintenance requirement of $B$ bulls in comparison to $G$ bulls, but no difference between $\mathrm{B}$ and $\mathrm{H}$ bulls. The aim of this study was to look for differences in digestion parameters between the breeds of cattle. Nutrient digestion gives an estimate of how effective an animal is in making energy in feed available for absorption.

The results of Table 3 show that, on the average, no significant difference exists between $\mathrm{G}$ and $\mathrm{B}$ bulls when digesting diets with a high variation of nutrient content. However, digestion capacity in B bulls seemed to be greater than in G bulls when diets with a low and high cellulose/starch ratio were fed. The high depression of digestibility of diet 1 by the increase of the nutrition level from 1.1 to 1.9 was lower in $\mathrm{B}$ bulls than in $\mathrm{G}$. With this diet and the straw one, digestibility of OM was higher $(\mathrm{P}<0.05)$ in $\mathrm{B}$ bulls when compared with $\mathrm{G}$ bulls. This can be explained by differences in the rumen volume and in the MRT of the particulate digesta. The rumen volume was significantly larger in B bulls ( $\mathrm{P}<0.05$; Fig. 3 ). When the nutrition level (NL) did not surpass 1.4 , MRT was also higher in this breed $(29.2 \pm 1.9$ vs. $30.8 \pm 2.2, n=40$, $\mathrm{P}<0.05$, Fig. 4). This indicates the digesta stays longer in the gastro-intestinal tract 
whereby the degree of digestion rises (Table 3). The smaller digestive system in robust breeds of cattle in comparison to purebred like Holstein or Jersey was discussed by McDOWELL et al. (1996). HUNTER and SIEBERT (1985) found a lower MRT of digesta in Brahmans compared with Herefords. The lower influence of NL on MRT in $\mathrm{G}$ animals than in B animals (Fig. 4) can not be explained by the difference in rumen volume (Fig. 3). Perhaps there exists a compensatory effect in the postruminal tract.

The digestibility of $\mathrm{OM}$ and cellulose (Tab. 4) was significantly lower $(\mathrm{P}<0.05)$ in $\mathrm{H}$ animals than in $\mathrm{B}$ animals. The lower digestibility in $\mathrm{H}$ was associated with a significantly $(\mathrm{P}<0.05)$ lower MRT $(25.3 \pm 2.4$ vs. $28.6 \pm 2.3 \mathrm{~h}$, all treatments were pooled; Fig. 4). The influence of the environmental temperature on particulate MRT and digestibility was small in both breeds. MRT revealed a rising tendency in both breeds (Fig. 2) as the temperature was increased from 3 to $30^{\circ} \mathrm{C}$. In contrast to WARREN et al. (1974) we could not confirm that increased MRT in a warm environment was associated with increased digestibility of organic matter. The ability to digest nutrients at an intermediate temperature $\left(18^{\circ} \mathrm{C}\right)$ appeared to be similar to that at $3{ }^{\circ} \mathrm{C}$ but higher than at $30^{\circ} \mathrm{C}$ (Table 4). The pattern of VFA was not influenced by the temperature treatment but VFA levels were highest at $18^{\circ} \mathrm{C}$ (Table 5).

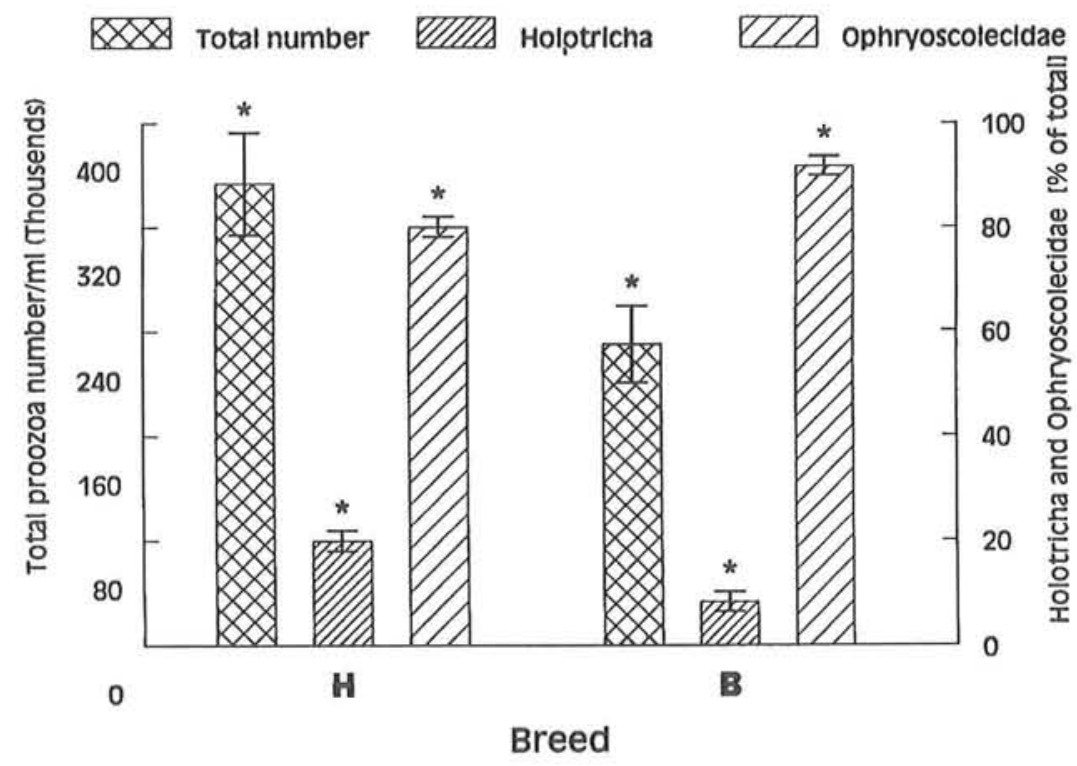

Fig. 1: Total number and composition of rumen protozoa in Exp. II (Anzahl und Zusammensetzung der Protozoen im Exp. II) 


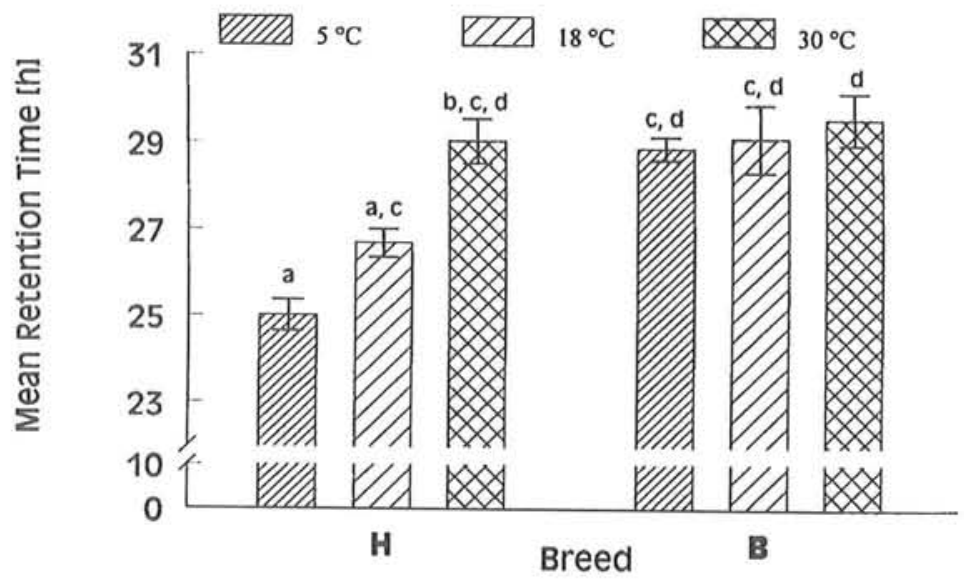

Fig. 2: Effect of environmental temperature on mean retention time (MRT) of particulate digesta (Einfluss der Umgebungstemperatur auf die mittlere Retentionszeit (MRT) dęr partikelgebundenen Digesta)

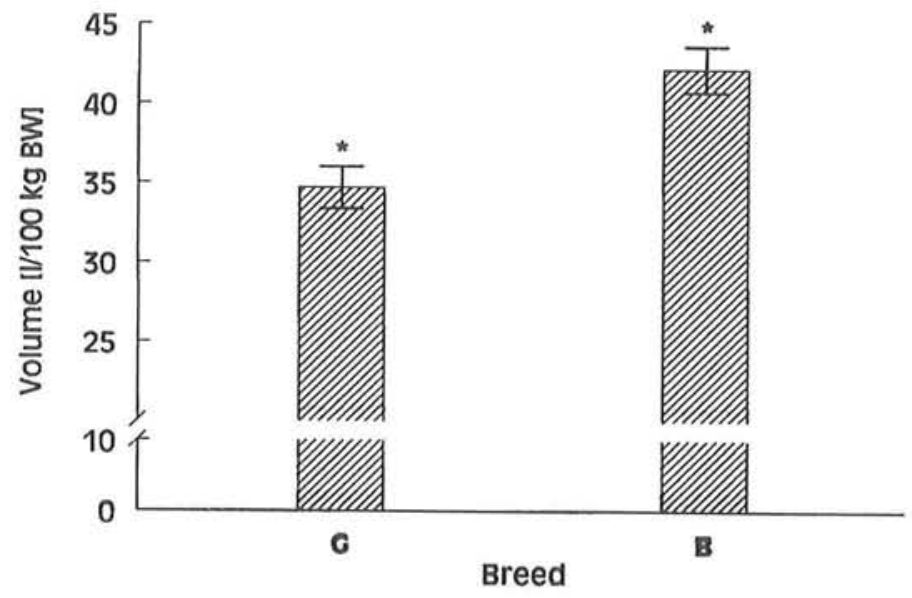

Fig. 3: Rumen volume of Galloway and Black-White Dairy cattle (Pansenvolumen von Galloway und Schwarzbunten Rindern) 

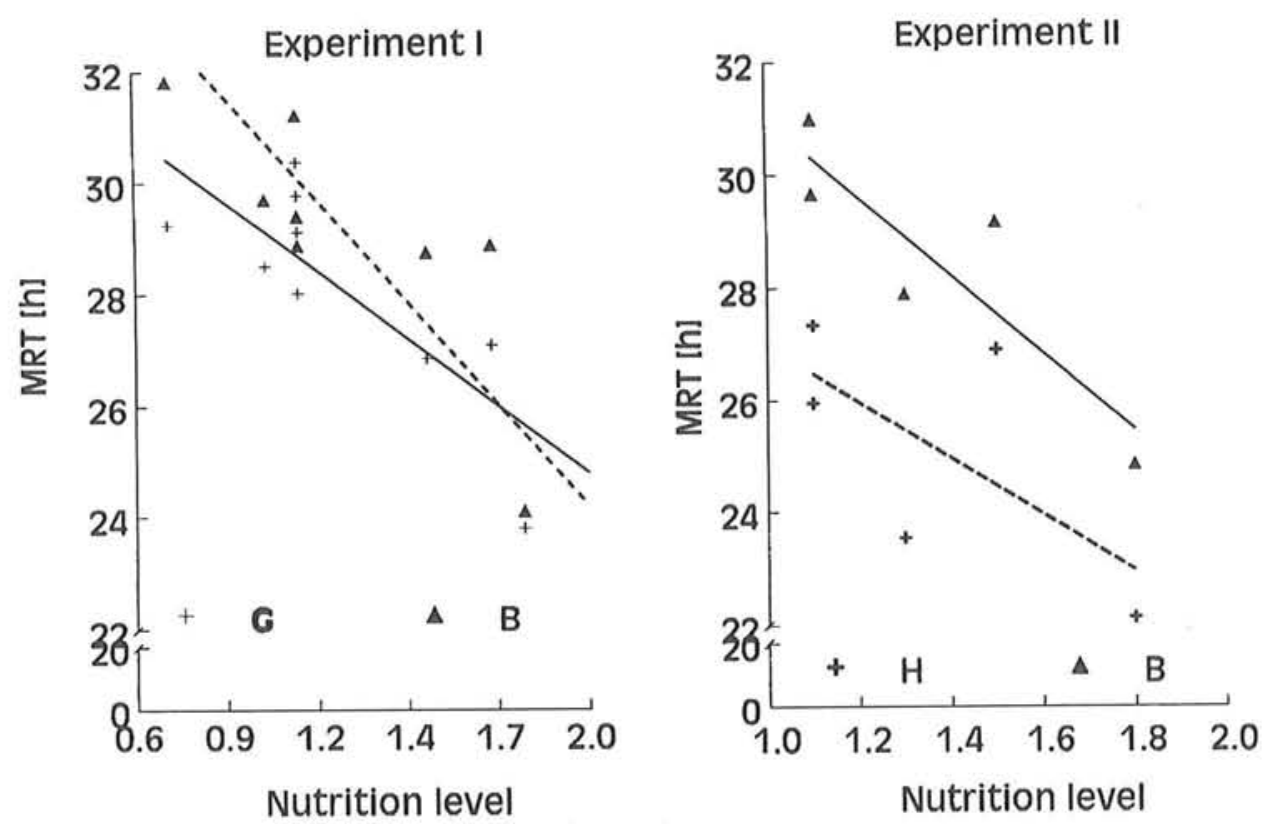

Fig. 4: Influence of Nutrition level (NL) on mean retention time (MRT) of digesta flow marker (Einfluss des Ernăhrungsniveaus (NL) auf die mittlere Retentionszeit (MRT) des Digestaflussmarkers)

Experiment. I:

$\mathrm{MRT}_{\mathrm{G}}=33.4-4.3 \cdot \mathrm{NL} ; \mathrm{RSD}=1.2$

$\mathrm{MRT}_{\mathrm{B}}=37.3-6.6 \cdot \mathrm{NL} ; \mathrm{RSD}=1.7$

Experiment. II:

$\mathrm{MRT}_{\mathrm{H}}=32.0-5.0 \cdot \mathrm{NL} ; \mathrm{RSD}=2.0$

$\mathrm{MRT}_{\mathrm{B}}=37.9-6.9 \cdot \mathrm{NL} ; \mathrm{RSD}=1.3$

Unfortunately, the results of the $\mathrm{H}$ bulls at $30^{\circ} \mathrm{C}$ cannot be compared with those of the $\mathrm{B}$ bulls. The rise of MRT in $\mathrm{H}$ bulls at $30^{\circ} \mathrm{C}$ can be associated with reduction in feed intake that occurred as a thermoregulatory response at this temperature. At this high temperature the $\mathrm{H}$ bulls refused to eat the total diet.

Rumen fermentation differed between the breeds. Rumen $\mathrm{pH}$ was 0.1 unit higher $(\mathrm{P}<0.05)$ in $\mathrm{B}$ bulls than in $\mathrm{G}$ or $\mathrm{H}$ bulls (Table 5). Surprisingly, the molar proportion of propionate of the volatile fatty acids was higher and the acetate/propionate ratio was lower $(\mathrm{P}<0.05)$ in the former. Consequently, the content of glucogenic energy of the volatile fatty acids produced in the rumen is higher in $\mathrm{B}$ bulls. However, the differences were small and moreover interactions existed between breed and diet. The lower rumen ammonia level in B bulls as compared to $\mathrm{H}$ bulls $(\mathrm{P}<0.05)$ was associated with a lower number of protozoa and a higher proportion of Ophryoscolecidae. Protozoa stimulate significantly the rate of bacterial protein turnover (WALLACE and McPHERSON, 1987) and reduce the yield of microbial protein in the rumen (IVAN et al., 2000). 
In conclusion, the data reported herein document differences in some parameters of digestion between B bulls as an intensively used breed of cattle and G or $\mathrm{H}$ bulls as extensively used breeds. However, the differences are small and should be insignificant for the nutrition requirement. The results show that B animals implement a more efficient ruminal digestive process than $\mathrm{G}$ or $\mathrm{H}$ bulls. The effect of environmental temperature on the digestive process is small. Further investigations are necessary in order to distinguish between ruminal and postruminal digestion in the individual breeds of cattle.

\section{Reference}

ARCHER, J.A.; RICHARDSON, E.C.; HERD, R.M.; ARTHUR, P.F.: Potential for selection to improve efficiency of feed use in beef cattle: a review. Aust. J. Agric. Res. 50 (1999), 147-161

BLAXTER, K.L,; GRAHAM, N. Mc.; WAINMAN, F.W.:

Some observations on the digestibility of food by sheep, and on related problems. Brit. J. Nutr. 10 (1956), 69-91

BRANDT, M.; ALLAM, S. M.: Analytik von $\mathrm{TiO}_{2}$ im Darminhalt und Kot nach Kjeldahlaufschluss. Arch. Anim. Nutr. 37 (1987), 453454.

DOGIEL, V.A.:

Monographie der Familie Ophryoscolecidae. Arch. Protistenkd., 59 (1927), 1-288

FERBER, K.E.; WINOGRADOWA-FEDEROWA, T.:

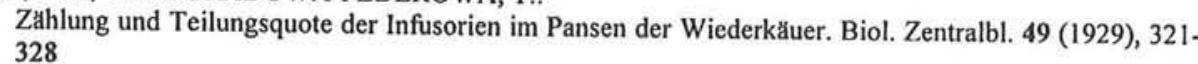

FRISCH, J.E.; VERCOE, J.E.:

An analysis of growth of different cattle genotypes reared in different environments. J. Agric. Sci., Cambridge, 103 (1984), 137-153

GEISSLER, CH.; HOFFMAN, M.; HICKEl, B.:

Ein Beitrag zur gaschromatographischen Bestimmung fluchtiger Fettsäuren. Arch. Anim. Nutr. 26 (1976), 123-129:

HUNGATE, R.E.:

The rumen and its microbes. Academic Press, New York, 1966

HUNTER, R.A.; SIEBERT, B.D.:

Utilization of low-quality roughage by Bos taurus and Bos indicus cattle. 2. The effect of rumendegradable nitrogen and sulphur on voluntary food intake and rumen characteristics. Brit. J. Nutrit. 53 (1985), 649-656

IVAN, M.; NEILL, L.; ENTZ, T.:

Ruminal fermentation and duodenal flow following progressive inoculations of fauna-free wethers with major individual species of ciliate protozoa or total fauna. J. Anim. Sci. 78 (2000), $750-759$

JENTSCH, W.; MATTHES, HEIDE-DÖRTE; DERNO, M; WEGNER, J.; VOIGT, J.; LÖHRKE, B.;

NÜRNBERG, K.; BEYER, M.:

Untersuchungen zum Stoffwechsel, zur Wärmeproduktion, zum Verhalten und zur Morphologie von

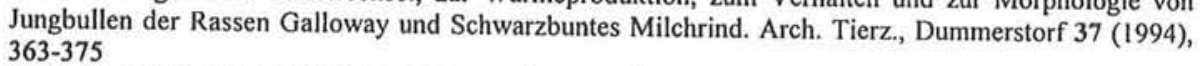

JENTSCH, W.; DERNO; M.; MATTHES, HEIDE-DÖRTE; LÖHRKE, B.; KUHLA, S.; SCHOLZE, H.: Ergebnisse aus Stickstoff- und Energieumsatzmessungen an adaptiv differenten Rindern. Arch. Anim. Nutr. 48 (1995), 159-171

KENNEDY, P.M.:

Ruminal and intestinal digestion in Brahman crossbreed and Hereford cattle fed alfalfa or tropical pasture hay. J. Anim. Sci. 55 (1982), 1190-1199

MCDOWELL, R.; E. WILK J. C; TALBOTT C. W.:

Economic Viability of Crosses of Bos taurus and Bos indicus for Dairying in Warm Climates. J. Dairy Sci. 79 (1996), 1292-1303 
NAGEL, S.; PIATKOWSKI, B.:

Untersuchungen des Pansenvolumens und der Pansenmasse von Milchkllhen.

Arch. Anim. Nutr. 22 (1972), 449-456

NAUMANN, C.; BASSLER, R.:

Die chemische Untersuchung von Futtermitteln. In: Handbuch der Landwirtschaftlichen Versuchs- und Untersuchungsmethodik. Methodenbuch, Bd. III, VDLUFA-Verlag, Darmstadt, 1988

STEGER, H.; VOIGT, J.; PIATKOWSKI, B.:

Vergleichende Untersuchungen über die Entnahme von Pansensaft durch Fistel und Oesophagus. Arch. Anim. Nutr. 18 (1968), 190-204

VOIGT, J.; STEGER, H.: Zur quantitativen Bestimmung von Ammoniak, Harnstoff und Ketokorpern in biologischem Material mit Hilfe eines modifzierten Mikrodiffusionsgefaßßes. Arch. Anim. Nutr. 17 (1967), 289-293

WALLACE, R.J.; McPHERSON, C.A.: Factors affecting the breakdown of bacterial protein in rumen fluid. Brit. J. Nutr. 58 (1987), 313-323

WARREN, W.P.; MARTZ, F.A.; ASSAY, K.H.; HILOLERBRAND, E.S.; PAYNE, C.G.; VOGT, J.R.:

Digestibility and rate of passage by steers fed tall fescue, alfalfa and orchad grass hay in 18 and $32^{\circ} \mathrm{C}$ ambient temperature. J. Anim. Sci. 39 (1974), 93-96

ZWIERZ, P.; KUHLA, S.; WEISSBACH, F.:

Zur Schătzung des energetischen Futterwertes anhand von analytisch bestimmbaren Kriterien. 1. Mitt.: Prüfung eines Vorschlages zur Veränderung der Weender Futtermittelanalyse. Arch. Anim. Nutr. 31 (1981), 395- 401

Received: $2000-08-30$

Accepted: 2000-09-29

\section{Authors' address}

Dr. sc. rer. nat. JÜRGEN VOIGT, Dr. habil. agr. WERNER JENTSCH,

Dr. rer. nat. SIEGFRIED KUHLA, Prof. Dr. habil. agr. HEIDE-DÖRTE MATTHES,

Dr. rer, nat. MICHAEL DERNO

Forschungsinstitut fur die Biologie landwirtschaftlicher Nutztiere

Wilhelm-Stahl-Allee 2

D-18196 Dummerstorf

Germany

E-Mail: voigt@fbn-dummerstorf.de 